\title{
The Appropriation of Isa 6:9-10 to the Parables of Jesus: Implications for the Synoptic Problem
}

Jonathan Lo

Hong Kong Baptist Theological Seminary

In all three Synoptic Gospels, the meaning and significance of the Parable of the Sower is closely linked to a reference to a passage of Hebrew scripture attributed to the prophet Isaiah. The quotation, Isa $6: 9-10$, is taken from a dialogue from the story of Isaiah's commissioning ${ }^{1}$ to become a prophet. After Isaiah accepts his divine mission and consents to being sent, God gives him a perplexing message for the people of Judah:

"Go and say to this people: 'Keep listening, but do not comprehend; keep looking, but do not understand.' Make the mind of this people dull, and stop their ears, and shut their eyes, so that they may not look with their eyes, and listen with their ears, and comprehend with their minds, and turn and be healed." (Isa 6:9-10)

The reference to Isaiah is directly linked to Jesus's teaching in parables in general, and the Parable of the Sower in particular. ${ }^{3}$ This connection can be clearly seen by observing the placement of the quotation and by noting the contextual markers relating the Isaianic quote to Jesus' parables. The quotation of Isaiah is located within an ABA' chiastic structure, (France, 2002: 193) sandwiched between Jesus's public narration of the Parable of the Sower and his private interpretation of the parable for his disciples. ${ }^{4}$ It appears in a

1 It is debated whether this is a straight forward call/commissioning narrative or a story that telescopes the destruction of Judah.

2 Unless otherwise noted, direct quotations from the Bible in this essay are taken from the New Revised Standard Version.

3 Luke makes the connection of Isaiah 6 to the Parable of the Sower explicit.

4 The "Parable of the Soils" also appears in the Nag Hammadi Coptic Text, Gospel of Thomas, but there it stands in isolation, without the allegorical interpretation or the crux interpretum. Some have suggested that Thomas

William Loader, Boris Repschinski, Eric Wong (Eds.)

Matthew, Paul, and Others: Asian Perspectives on New Testament Themes

(C) 2019 innsbruck university press, ISBN 978-3-903187-66-5, DOI 10.15203/3187-66-5 
paragraph that provides the crux interpretum, the "key to understanding this parable" (Snodgrass, 2008: 157), and perhaps, the reason why Jesus teaches in parables at all: ${ }^{5}$

A. Jesus tells the Parable of the Sower Publicly (Matt 13:1-9; Mark 4:1-9; Luke 8:5-8)

B. The Isaianic Quotation/ Crux Interpretum (Matt 13:10-17; Mark 4:10-12; Luke 8:9-10)

A'. Jesus interprets the Parable of the Sower in Private (Matt 13:18-23; Mark 4:13-20; Luke 8:11-15)

The quotation of Isa 6:9-10 is introduced with a brief explanation of how it relates to Jesus teaching in parables. Mark's version (Mark 4:11-12) is somewhat furtive; Jesus tells his disciples that while they have been given the

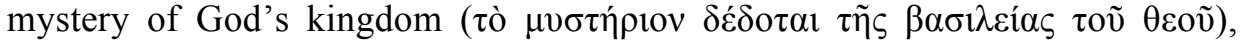
everything is in parables ( $\dot{\varepsilon} v \pi \alpha \rho \alpha \beta$ o $\lambda \alpha \tilde{\mathrm{i}} \varsigma$ ) to those on the outside in order that (iv $\alpha$ ) "although seeing, they might see but not perceive..." Luke's version of the Isaianic quotation is much more concise. Whereas Mark follows Isaiah's tripartite structured: "Seeing, you will see but never see..." (Mark 4:12/Isa 6:9 $[\mathrm{LXX}])$, Luke condenses the phrase into a doublet: "seeing, they will not see..." (Luke 8:10) Luke also omits the part of the quotation about the possibility of turning and being forgiven. In Matthew (Matt 13:10-17), the logical connection between the Isaianic quotation and Jesus speaking parables is made even more explicit. Matthew's Jesus says: "For this reason I speak to them in parables, because (ő $\tau)$ "seeing they do not see..." (Matt 13:13) After following Mark in quoting a bit of Isa 6:9-10, Matthew asserts even more forcefully that the prophecy of Isaiah is fulfilled among those who reject Jesus' teaching, and proceeds to recite a fuller and more precise quotation of Isa 6:9-10. ${ }^{6}$

Variations like these offer a valuable opportunity to study the Synoptic Gospels' literary relationships with each other, and in particular, the citational patterns of each evangelist and what they reveal about the authors' literary

contains the most primitive form of the parable, with the addition of the interpretation as a secondary layer of tradition (Horman, 1979; Lane, 1974: 156; Snodgrass, 2008: 151).

$5 \quad$ Arida (1994: 211); (Snodgrass, 2008: 171); Cf. Mark 4:10-12; Matt 13:10-17; Luke 8:9-10.

6 Hultgren (2000: 462-463).

William Loader, Boris Repschinski, Eric Wong (Eds.)

Matthew, Paul, and Others: Asian Perspectives on New Testament Themes

(C) 2019 innsbruck university press, ISBN 978-3-903187-66-5, DOI 10.15203/3187-66-5 
intentions and habits. The different ways in which the evangelists appropriated the Isaianic text also enables us to see how they might have understood and applied that text to serve their own literary purposes within their respective theological frameworks. There are numerous publications on the use of Isa 6:910 in Matthew, Mark, and Luke within the area of intertextual studies-but this paper will attempt to steer the conversation in a different direction, towards the area of compositional theory. As interesting as this pericope is for studying the use of the Hebrew scriptures in the New Testament, it also provides many insights for enhancing our knowledge regarding the Synoptic Problem. In the words of David Wenham, who attempted a similar project on the interpretation of the Parable of the Sower, "Would a different solution to the Synoptic Problem make better sense of the text?"7

The fact that there is an obvious interrelationship between Matthew, Mark, and Luke in this passage, and that a clear reference to a known Hebrew scripture can be ascertained, provides a good foundation for asking further probing questions about the gospels and the nature of their composition. In this paper, I will begin with a discussion of why Markan priority still makes the best sense of the literary relationships in this pericope. I will then discuss the potential source material of the Isaiah quotation and survey the differences between the MT, LXX, and Targumic versions of the text. Next, I will survey the differences between the Synoptic Gospels in their use of Isa 6:9-10 and discuss the factors and motivations that may account for the variation. I will review the original context of Isa 6:9-10 and give an account of how each evangelist is appropriating Isaiah within their own narratives about the Parable of the Sower. Finally, I will discuss the implications such an investigation yields for the Synoptic Problem by testing three leading hypotheses within Markan Priority (the Two Document Hypothesis, the Farrer Hypothesis, and the Matthew Conflator Hypothesis) to see whether such citational patterns can be used to challenge or give traction to competing theories of authorship and composition.

Wenham's (1974: 299) conclusion from investigating the Synoptic interpretations of the Parable of the Sower passages is that there was a pre-Marcan source that all three evangelists knew, and that Mark is dependent on GMatthew (!), and that GLuke is dependent on Mark and Matthew (Wenham, 1974: 318-319; Wenham, 1972).

William Loader, Boris Repschinski, Eric Wong (Eds.)

Matthew, Paul, and Others: Asian Perspectives on New Testament Themes

(C) 2019 innsbruck university press, ISBN 978-3-903187-66-5, DOI 10.15203/3187-66-5 


\section{Introductory Issues}

In each of the gospels, the Isaiah quotation is a crucial part of Jesus's response to a question posed by his disciples. The striking similarities between the three versions of the story lead to the suggestion that there is some sort of literary dependence present. ${ }^{8}$ The same details, wording, and sequence of events can be found in each gospel: 1) the disciples ask Jesus a question about the parable/parables; 2) Jesus responds by telling them that they are privileged to be given knowledge about the mystery of the Kingdom of God, and 3) the scripture of Isa 6:9-10 holds the answer to why Jesus speaks in parables. The three versions also show a high degree of correspondence in terms of both vocabulary and sequence. For example, in terms of vocabulary, the words "parable"

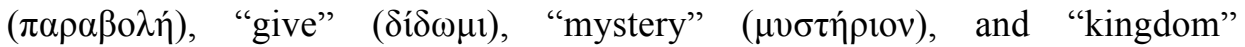
( $\beta \alpha \sigma \imath \lambda \varepsilon i ́ \alpha)$ appear in all three gospels. In each gospel version, the disciples ask Jesus a question, to which he responds in the same way, followed by a quotation of Isa 6:9-10. The gospels resemble one another to high degree, but what is the literary relationship between the three gospels?

\section{Markan Priority?}

There are several factors that favour the Markan Priority hypothesis, and many interpreters of the Parable of the Sower take this view. ${ }^{9}$ While the Matthean version is the lengthiest, this is because it includes an additional verse that is located elsewhere in Mark and the addition of some double tradition material. ${ }^{10}$ Upon closer analysis, it is Mark's version that contains the most detailMatthew and Luke are likely to be edited and abbreviated accounts that improve and condense Mark's language and remove extraneous information (Nolland, 1989: 377; Snodgrass, 2008: 152) For example, Mark mentions that it was not only the Twelve who ask Jesus a question, but also those "who were around

\footnotetext{
Pace Linnemann (1992: 155-176)

(Dungan, 1999: 340-341; Fitzmyer, 1985; Hultgren, 2000: 183) Pace (Farmer, 1964: 200; Wenham, 1972: 8)

10 Cf. Matt 13:12 // Mark 4:25: "For to those who have, more will be given, and they will have an abundance; but from those who have nothing, even what they have will be taken away." Double Tradition material: Matt 13:1617 // Luke 10:24: "But blessed are your eyes, for they see, and your ears, for they hear. Truly I tell you, many prophets and righteous people longed to see what you see, but did not see it, and to hear what you hear, but did not hear it."
}

William Loader, Boris Repschinski, Eric Wong (Eds.)

Matthew, Paul, and Others: Asian Perspectives on New Testament Themes

(C) 2019 innsbruck university press, ISBN 978-3-903187-66-5, DOI 10.15203/3187-66-5 
him." Matthew and Luke do not make such a distinction and simply refer to both as one group, the disciples. Similarly, Mark describes Jesus speaking

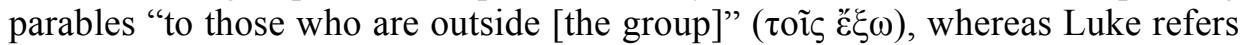

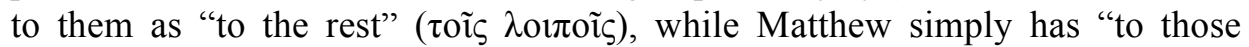

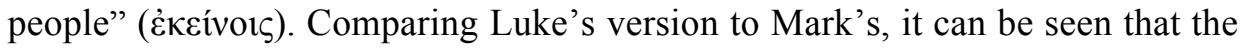
Luke has condensed Mark's language by using fewer words, adding the

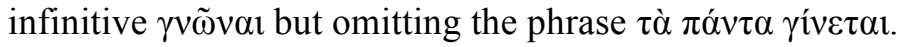

\begin{tabular}{|c|c|}
\hline Mark (17 Words) & Luke (14 Words) \\
\hline 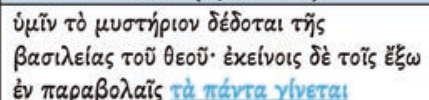 & 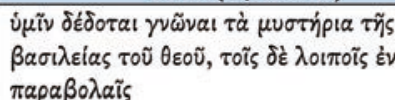 \\
\hline
\end{tabular}

Figure 1: Luke's Version is Shorter than Mark's Version

Another example is that while Mark says that the disciples are given the mystery of the kingdom, both Matthew and Luke insert the infinitive "to know" $(\gamma \vee \tilde{\omega} \vee \alpha i)$, making it the direct object of the verb $\delta \varepsilon \delta \delta o \tau \alpha$. The disciples are granted "knowledge" about the mystery of the kingdom, rather than being granted the mystery itself. This change makes better sense of the sentence's meaning and improves its clarity. "Similarly, while the word "mystery" ( $\mu \nu \sigma \tau \eta \dot{\rho t o v})$ is in the singular in Mark, it is pluralized by both Matthew and Luke $(\mu v \sigma \tau \eta \dot{\rho} \rho)$. This subtle change also improves the grammar of Mark, because "mystery," in context, corresponds to parables, which is in the plural. This change achieves agreement in number between the two subjects of comparisons.

\footnotetext{
11 Marcus observes that the phrase "those round him" should certainly be assumed to include the Twelve (Marcus, 1986: 74).

12 See also Marcus (1986: 86, n. 39)
}

William Loader, Boris Repschinski, Eric Wong (Eds.)

Matthew, Paul, and Others: Asian Perspectives on New Testament Themes

(C) 2019 innsbruck university press, ISBN 978-3-903187-66-5, DOI 10.15203/3187-66-5 


\begin{tabular}{|l|l|l|}
\hline \multicolumn{1}{|c|}{ Mark 4:11 } & \multicolumn{1}{c|}{ Matt 13:11-13 } & \multicolumn{1}{c|}{ Luke 8:10 } \\
\hline $\begin{array}{l}\text { "To you has been given the } \\
\text { mystery of the kingdom..." } \\
\text { (Singular) }\end{array}$ & $\begin{array}{l}\text { "To you it has been given to } \\
\text { know the mysteries of the } \\
\text { kingdom..." (Plural) }\end{array}$ & $\begin{array}{l}\text { "To you it has been given to } \\
\text { know the mysteries of the } \\
\text { kingdom..." (Plural) }\end{array}$ \\
$\begin{array}{l}\text { "To them everything is in } \\
\text { parables..." (Plural) }\end{array}$ & $\begin{array}{l}\text { "The reason I speak to them } \\
\text { in parables is..." (Plural) }\end{array}$ & $\begin{array}{l}\text { "But to others I speak in } \\
\text { parables..." (Plural) }\end{array}$ \\
\hline
\end{tabular}

Figure 2: Agreement of Number Between "Mysteries and Parables" in Matthew and Luke

Moreover, Mark's Greek is a bit clumsy with regard to the disciples' question and as a result it is unclear as to what exactly they were asking - this is something both Matthew and Luke attempt to improve. Mark uses the $3^{\text {rd }}$ person

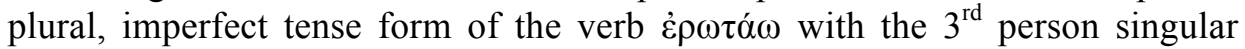

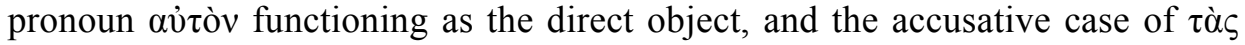
$\pi \alpha \rho \alpha \beta 0 \lambda \alpha$ $\alpha$ functioning as an accusative of respect or reference:(Wallace, 1996: 203) "The Twelve and those with Jesus were asking him concerning the parables." It is noteworthy that "the parables" ( $\tau \dot{\alpha} \varsigma \pi \alpha \rho \alpha \beta o \lambda \alpha ́ \varsigma)$ is pluralized, because it means that the disciples were not necessarily asking Jesus about the meaning of the Parable of the Sower (singular); their question was a broader one about the parables in general (France, 2002: 193; 2007: 510) Matthew clarifies the disciples' question by turning it into a question directly about the reason Jesus spoke in parables: "Why do you speak to them in parables?" ( $\delta i \grave{\alpha} \tau i ́$

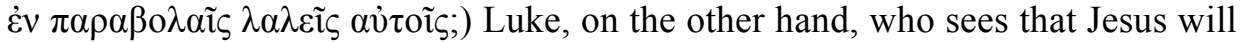
proceed to interpret the Parable of the Sower for his disciples in the following verses, changes the disciples' question into one about the meaning of the Parable of the Sower: ${ }^{13}$ "His disciples were asking him what [the meaning of]

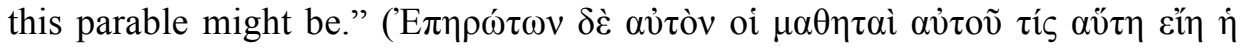
$\pi \alpha \rho \alpha \beta 0 \lambda \eta$.) In any case, the fact that Mark's version is the most ambiguous suggests that it is the most primitive form of the question upon which Matthew's and Luke's versions both depend.

13 Note that "parable" in Luke 8:9 is singular, as opposed to the pluralized form in Mark 4 and Matt 13. (Marshall, 1978: 321)

William Loader, Boris Repschinski, Eric Wong (Eds.)

Matthew, Paul, and Others: Asian Perspectives on New Testament Themes

(C) 2019 innsbruck university press, ISBN 978-3-903187-66-5, DOI 10.15203/3187-66-5 
In addition to the above, Matthew and Luke appear to be dependent on Mark's text rather than quoting Isaiah directly. This can be determined on the basis of the language and sequence of ideas that appear in the quotation. When Mark's quotation is compared to the LXX version of Isa 6:9-10, some striking resemblances in terms of vocabulary and content can be observed. For example, the distinction between $\beta \lambda \dot{\varepsilon} \pi \omega$ as "seeing" and ó $\alpha \dot{\alpha} \omega$ as "perceiving" is maintained, as is the parallel between $\dot{\alpha} \kappa o v ́ \omega$ (hearing) and $\sigma v v i ́ \eta \mu$ (understanding). Isaiah's Hebraic and idiomatic use of an infinitive absolute

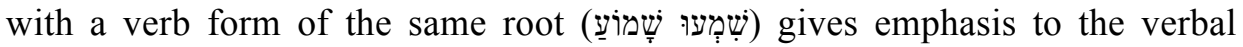
meaning "שמע" ("you will surely hear") (Marshall, 1978: 322) This pattern is

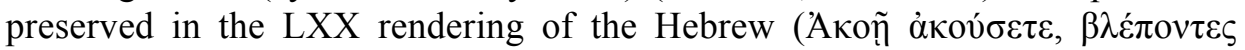

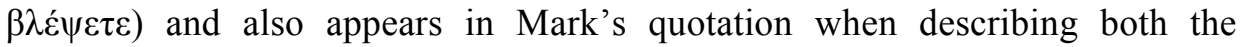

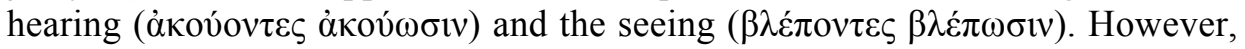
Mark also adapts and modifies Isaiah in some significant ways, and these adaptations are also found in Matthew and Luke.

\section{The Source Materials}

In context, the words of Isaiah depict God preventing repentance so that a total destruction can come upon Judah in judgement for her rebellion and unfaithfulness. ${ }^{14}$ The overall story serves to accentuate Judah's guilt and to provide a justification for God's punishment in the shape of Judah's eventual downfall. The "Commissioning of Isaiah" is a tragic story, because had the people of Judah listened to Isaiah and repented, they might have been spared the coming disaster. However, due to their dullness of mind and failure to perceive the obvious, they will be unable to heed Isaiah's warnings and are fully deserving of the coming judgment. ${ }^{15}$ The crux of the story of Isaiah's commission is that Judah is guilty of rebellion against God and her idolatry has rendered her unable to understand and respond appropriately to God's message of salvation. Isaiah's prophetic task is a complicated one- he is to preach the message of God's salvation as well as the people's need for repentance even though he knows they will not be receptive to his preaching. Mark adapts and

14 Cf. Isa 10:10-11; 31:7; 42:8; 44:9, 17; 45:16, 20; 46:1; 48:5; 57:13; 66:3 (Oswalt, 1986: 187-188).

15 Isa 6 comes on the heels of Isa 1-5, where themes of hardening and impending judgment have already repeatedly surfaced. (Snodgrass, 2008: 159; Watts, 2017: 73-74)

William Loader, Boris Repschinski, Eric Wong (Eds.)

Matthew, Paul, and Others: Asian Perspectives on New Testament Themes

(C) 2019 innsbruck university press, ISBN 978-3-903187-66-5, DOI 10.15203/3187-66-5 
condenses Isa 6:9-10 in several notable ways, but it is helpful to first look at the structure and content of the hypothetical source materials. Although Mark's language is similar to the LXX, it is also possible that he relies on a Greek text that was closer to the Hebrew or Targumic versions of Isaiah, or he produced his own translation (Lane, 1974: 158) For comparison, the MT, LXX, and Targum to Isa 6:9-10 are listed and compared below-each comprises two primary thought units surrounding the actions "Go and say..." and "Make dull...": ${ }^{16}$

\begin{tabular}{|l|l|l|l|}
\hline & \multicolumn{1}{|c|}{ Isa 6:9-10 (MT) } & \multicolumn{1}{c|}{ Isa 6:9-10 (Targums) } & \multicolumn{1}{c|}{ Isa 6:9-10 (LXX) } \\
\hline Unit 1 & $\begin{array}{l}\text { Go and say to this } \\
\text { people: Keep listening, } \\
\text { but do not comprehend; } \\
\text { keep looking, but do not } \\
\text { understand.' }\end{array}$ & $\begin{array}{l}\text { Go and say to this people } \\
\text { who indeed hears, but } \\
\text { does not understand, and } \\
\text { who indeed sees, but does } \\
\text { not know. }\end{array}$ & $\begin{array}{l}\text { Go and say to this people: In } \\
\text { listening you will listen and } \\
\text { never comprehend; and } \\
\text { looking you will look and } \\
\text { never understand. }\end{array}$ \\
\hline Unit 2 & $\begin{array}{l}\text { Make the mind of this } \\
\text { people dull, and stop } \\
\text { their ears, and shut their } \\
\text { eyes, so that they may } \\
\text { not look with their eyes, } \\
\text { and listen with their } \\
\text { ears, and comprehend } \\
\text { with their minds, and } \\
\text { turn and be healed." }\end{array}$ & $\begin{array}{l}\text { Make the mind of this } \\
\text { people stupid, and make } \\
\text { his ears heavy, and stop } \\
\text { up his eyes lest they see } \\
\text { with their eyes and hear } \\
\text { with their ears, and } \\
\text { understand with their } \\
\text { minds, and repent and it } \\
\text { be forgiven them. }\end{array}$ & $\begin{array}{l}\text { For the mind of this people } \\
\text { is dull, and their ears are } \\
\text { hard of hearing and they } \\
\text { shut their eyes lest they } \\
\text { might see with their eyes } \\
\text { and hear with their eyes and } \\
\text { understand with their minds } \\
\text { and turn and I will heal } \\
\text { them. }\end{array}$ \\
\hline
\end{tabular}

Figure 3: Comparing the MT, LXX, and Targumic Versions of Isa 6:9-10

Several important observations can be made. First, the passage begins with God commissioning Isaiah to speak to "this people," and in the MT and LXX versions, the message he is to deliver. In the Targum to Isaiah, the message Isaiah is to speak is not mentioned; the hearing/seeing motif is a description of the people. Second, the Hebrew and Aramaic versions of Isa 6:9-10 also have a slightly different emphasis compared to the LXX. In the Hebrew and Aramaic, the prophet Isaiah has a role in hardening the people's hearts; his preaching will

16 In addition to the MT, LXX, and Targumic versions, Isa 6:9-10 can also be found in the Dead Sea Scrolls $\left(1 \mathrm{QIsa}{ }^{\mathrm{a}}\right)$ and the Peshitta with minor variations.

William Loader, Boris Repschinski, Eric Wong (Eds.)

Matthew, Paul, and Others: Asian Perspectives on New Testament Themes

(C) 2019 innsbruck university press, ISBN 978-3-903187-66-5, DOI 10.15203/3187-66-5 
make the people's minds even more dull as judgement against them (J. D. W. Watts, 2005: 109) In the LXX, this element is softened and downplayed; the prophet merely testifies to the people's rebellious condition that prevents repentance rather than causing it. ${ }^{17}$ Third, a chiastic pattern can be observed within the second thought unit in all three versions, in which mind, ear, and eye are in parallel to each other:

\section{A. Make the mind of this people dull \\ B. Stop their ears}

\section{Shut their eyes}

SO THAT

B'. And listen with their ears

$$
\text { C'. so they may not look with their eyes }
$$

\section{A'. And comprehend with their minds}

Fourth, in both the MT and the LXX versions, second person verbs are used in the first section, while both second person and third person verbs are used in the second section. This is because the first section contains the message that Isaiah is to deliver to the people in direct speech format: "Go and say to this people: "(You) Keep listening, but do not comprehend; (You) keep looking, but do not understand..." The second section continues with God's command to Isaiah to "make their hearts dull" as well as commentary about the people, and thus third person verbs are used. "Make minds of the people are dull... lest they do not look with their eyes or hear with their ears, etc." In the Targum to Isaiah, Isaiah's direct speech is removed and articulated with the third person verb, so that both sections use third person verbs: "Go and say to this people, who surely hears but do not understand..."

Finally, the second section concludes with a startling revelation-had the people repented and heeded Isaiah's warnings, they might have been healed from their idolatrous condition and spared the coming disaster. The Targum to Isaiah understands "healing" to be a metaphor for forgiveness and renders the Aramaic translation as such. The language of blindness and deafness connotes the Isaianic theme of idolatry by evoking an image of an idol that is fashioned

17 (France, 2002: 200; Hagner, 2000: 374). 
in human likeness (e.g. possessing sensory organs like the eyes, ears, and mouth) but lacks the ability to see, hear, and speak. ${ }^{18}$ Those who engage in idolatry are described as resembling idols because even though they have eyes and ears, they do not really see or hear; they fail to acknowledge God (e.g. Isa 1:1-3) and they do not understand him (e.g. Isa 6:10; 44:18) — they are devoid of spiritual insight (Marcus, 1986: 104) For this reason, God's eschatological deliverance of Judah is described in terms of a healing of the sensory organs and a restoration of the ability to sense, to perceive, to understand. ${ }^{19}$ The description of a people whose "eyes are shut" and whose "minds do not comprehend" in Isa 6:9-10 also appears in Isa 44:18 in connection to those who make idols and who worship them:

"All who make idols are nothing, and the things they delight in do not profit; their witnesses neither see nor know. And so they will be put to shame. Who would fashion a god or cast an image that can do no good? Look, all its devotees shall be put to shame; the artisans too are merely human... They do not know, nor do they comprehend; for their eyes are shut, so that they cannot see, and their minds as well, so that they cannot understand"' (Isa 44:9-11, 18).

\begin{tabular}{|l|l|}
\hline \multicolumn{1}{|c|}{ Isa 44:18 } & \multicolumn{1}{c|}{ Isa 6:10 } \\
\hline $\begin{array}{l}\text { They do not know, nor do they comprehend; } \\
\text { for their eyes are shut, so that they cannot } \\
\text { see, and their minds as well, so that they } \\
\text { cannot understand. }\end{array}$ & $\begin{array}{l}\text { Make the mind of this people dull, and stop } \\
\text { their ears, and shut their eyes, so that they } \\
\text { may not look with their eyes, and listen with } \\
\text { their ears, and comprehend with their minds, } \\
\text { and turn and be healed }\end{array}$ \\
\hline
\end{tabular}

Figure 4: Blindness and Deafness as the Language of Idolatry in Isaiah

The motif of a lack of perception and understanding is clearly associated with the lack of spiritual insight as a result of idolatry-even the similarity of language used to describe idolatry is striking:

18 E.g. Isa 42:18-19; 43:8; 56:10. This theme can also be found in several other Hebrew scriptures, e.g. Ps. 115:3-8; 135:15-18; Jer 5:20-29; Ezek 12:1-6.

19 For example, Isaiah 35:5 speaks of the day when "eyes of the blind being opened" and the "ears of the deaf unstopped." See also Isa 29:18; 43:8. See also (Arida, 1994: 217)

William Loader, Boris Repschinski, Eric Wong (Eds.)

Matthew, Paul, and Others: Asian Perspectives on New Testament Themes

(C) 2019 innsbruck university press, ISBN 978-3-903187-66-5, DOI 10.15203/3187-66-5 
Judah's eventual downfall is not because of God's indifference nor Isaiah's incompetence. The responsibility for the impending disaster falls squarely upon the shoulders of the idolatrous who reject God's message, which was intended to call them to repentance and salvation-but will now result in judgment. Rikki Watts asserts that: "In sum, Isa. 6:9-13 is Yahweh's judicial response, effected through the parabolic proclamation of his prophet, to an idolatrous Judah, whose protestations of faithfulness are belied by the leaders' rejection of Yahweh's instruction." (Watts, 2007: 152) Some scholars see Deut 29:2-4 as the inspiration behind the language of seeing and hearing in Isaiah: (Watts, 2007: 172)

Moses summoned all Israel and said to them: You have seen all that the LORD did before your eyes in the land of Egypt, to Pharaoh and to all his servants and to all his land, the great trials that your eyes saw, the signs, and those great wonders. But to this day the LORD has not given you a mind to understand, or eyes to see, or ears to hear. (Deut 29:24)

Deut 29 is a pivotal moment within Israel's Exodus story. After Israel has witnessed God's mighty deeds with their own eyes, will they now choose covenant faithfulness to the word of God's commandment? How will Israel respond to God's mighty deliverance? According to deutero-Isaiah, in the same way that some chose not to respond to God's call to faithfulness in the first Exodus, there are those who will fail to respond to God in the New Exodus (Arida, 1994: 217; Marcus, 1999: 508) Hence, Isa 6, a text which recalls God's call to Israel to be faithful during the first Exodus, became a "classic text" in Judaism for describing Israel's hardness of heart, inspiring other Hebrew prophets to describe the nation's rebelliousness and unfaithfulness using similar terms (Evans, 1989; Snodgrass, 1994: 40-41) It is perhaps not surprising that the Synoptic evangelists also used this passage to describe opposition to Jesus's teaching in the New Testament. ${ }^{20}$ The fact that they were quoting Isa 6:9-10 and not Jeremiah nor Ezekiel can be ascertained through a comparison of the quoted texts with the original. Instead, the gospel quotations contain many formal, lexical, and grammatical similarities with the Isaianic text, with Matthew going

20 The connection of Isa 6:9-10 to the "hardness of heart" motif appears to be a common one. It is also used to refer to the disciples hardened hearts (Mark 8:18), the Jews' rejection of Jesus (John 12:39-40) and of Paul (Acts 28:26-27) (Evans, 1989; Hagner, 2000: 734; Osborne, 2010: 510-511).

William Loader, Boris Repschinski, Eric Wong (Eds.)

Matthew, Paul, and Others: Asian Perspectives on New Testament Themes

(C) 2019 innsbruck university press, ISBN 978-3-903187-66-5, DOI 10.15203/3187-66-5 
as far to identify the quotation as "the prophecies spoken by the Isaiah" ( $\dot{\eta}$

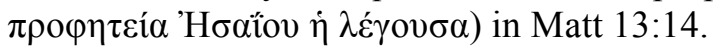

\section{The Synoptic Use of Isa 6:9-10}

\section{Mark's Use of Isaiah}

In light of the above, although Mark shares some common vocabulary with the LXX of Isaiah, his quotation of Isaiah resembles more the sense of the MT and Targumic versions, where the speech of the prophet plays a more prominent role in confounding the listener. Mark's use of Isaiah is periphrastic;(Snodgrass, 2008: 153; Watts, 2017: 72) he condenses and adapts the Isaianic text in several distinctive ways to incorporate it into Jesus's saying, so that when we see these features in Matthew and Luke, we know they are using Mark's quotation rather than directly quoting Isaiah (Watts, 2007: 151)

\begin{tabular}{|c|c|c|c|}
\hline MT & LXX & Targums & GMark \\
\hline $\begin{array}{l}\text { Go and say to this } \\
\text { people: Keep listening, } \\
\text { but do not } \\
\text { comprehend; keep } \\
\text { looking, but do not } \\
\text { understand.' Aake the } \\
\text { dull, and stop their } \\
\text { ears, and shut their } \\
\text { eyes, so that they may } \\
\text { not look with their } \\
\text { eyes, and listen with } \\
\text { their ears, and } \\
\text { cemprehend with their } \\
\text { minds, and turn and be } \\
\text { healed." }\end{array}$ & 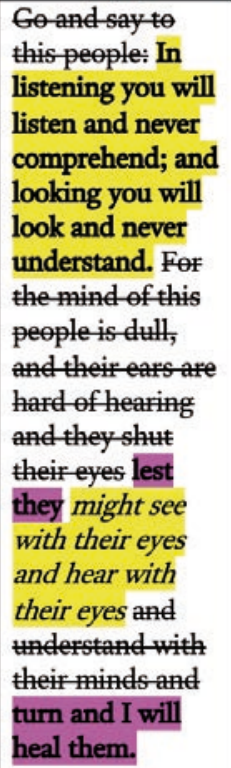 & $\begin{array}{l}\text { Go and say to this } \\
\text { people whe indeed } \\
\text { hears, but does not } \\
\text { understand, and who } \\
\text { indeed sees, but does } \\
\text { not know. Make the } \\
\text { stupid, and make his } \\
\text { ears heary, and stop } \\
\text { up his eyes } \\
\text { lest they see with their } \\
\text { eyes and hear with } \\
\text { their ears,-and } \\
\text { understand with their } \\
\text { minds, and repent and } \\
\text { it be forgiven them. }\end{array}$ & $\begin{array}{l}\text { [for those on the } \\
\text { outside everything is } \\
\text { in parables in order } \\
\text { that...] } \\
\text { They may indeed look, } \\
\text { but not perceive, and } \\
\text { may indeed listen, but } \\
\text { not understand; so } \\
\text { that they may not turn } \\
\text { again and be forgiven. }\end{array}$ \\
\hline
\end{tabular}

Figure 5: Mark's Use of Isa 6:9-10

Matthew, Paul, and Others: Asian Perspectives on New Testament Themes

(C) 2019 innsbruck university press, ISBN 978-3-903187-66-5, DOI 10.15203/3187-66-5 
What Mark does is to transpose Isaiah's "going and saying to this people" with Jesus speaking to the crowds in parables. He then quotes the second half of Isa 6:10 while using the language of verse 9 to describe the actions "seeing" and "hearing." Mark takes the language of the direct speech Isaiah is to deliver to the people in verse 9 ("hearing, you will hear but not understand... seeing you will see but not perceive...") and inserts it into the last clause of verse 10 , changing both the person of the verbs (second to third) and the chronological order (putting "seeing" before "hearing"). (Marcus, 1986: 76)

Markan scholar Rikki Watts has suggested that the order of seeing before hearing might reflect Mark's interest in "sight" in relation to Jesus' healing miracles; (Watts, 2007: 151) however, the dominant metaphor in Mark 4 is not "sight" but "hearing." ${ }^{21}$ The transposition might have taken place simply because it is the order that appears in verse 10. Originally, the second colon mentions the mind, ears, and eyes with this poetic arrangement: mind $->$ ears $->$ eyes $->$ eyes $->$ ears $->$ mind. Mark ignores the chiastic structure and begins his quotation with "eyes" at the last part of the sentence and omits the minds being made dull.

\section{Isaiah: mind $->$ ears $->$ eyes $->$ eyes $->$ ears $->$ mind \\ Mark: mind $->$ ears $->$ eyes $->$ eyes $->$ ears $->$ mind \\ *but uses the ear/eye pairing from verse 9}

Another, more likely, possibility is that Mark also has in mind other passages that contain this motif, such as Jer 5:21 and Ezek 12:2, which have "seeing" before "hearing." 22 For example, in Mark 8:18, when Jesus asks the disciples if they have eyes but "fail to see," and if they have ears but "fail to hear," Mark is

${ }^{21}$ Cf. Mark 4:9, 12, 15-16, 18, 20, 23-24, 33 (Swartley, 1994: 53; France 2002: 184; Green 1997: 322-323; Snodgrass, 2008: 152).

22 According to Snodgrass, both Jer 5:21 and Ezek 12:2 are borrowing from the language of Isa 6. (Snodgrass, 2008: 153-154) 
more clearly drawing upon the language of Jeremiah and Ezek rather than Isaiah, although all of these texts are related thematically. ${ }^{23}$

Mark condenses Isaiah's text and applies what was said about those who failed to understand Isaiah's message to those who do not now listen to Jesus. Mark applies the prophetic irony of Isaiah's commission to the ministry of Jesus, in that his apparent failure was foretold. ${ }^{24}$ The logic of the Isaiah passage is that the prophet's speech will further harden a rebellious people's hearts, eliminating any possibility of repentance and forgiveness until the decreed judgment is unleashed (Watts, 2007: 152). The passage is both tragic and ironic, because it underscores the pitiful condition of a recalcitrant people who choose to be obstinate to the very end, despite repeated warnings that should be simple to understand. Mark associates Jesus's teaching in parables to Isaiah's divinely commissioned message. Due to the people's hardened hearts, Jesus's teaching, which should have been the means to their salvation, will now become unintelligible to them, ensuring their eventual and deserved destruction. In the same way that the people in Isaiah's day ignored the prophet's message at their own peril, those who do not heed Jesus's message will meet a similar fate. ${ }^{25}$ In terms of narrative sequence, the Parable of the Sower, to which the Isaiah quotation is appended, proceeds from the Beelzebul controversy (Mark 3:2235 ), an event that prompts Jesus to begin teaching in parables. ${ }^{26}$ The Jewish scribes from Jerusalem "see" Jesus cast out demons but fail to "perceive" that he does this on behalf of God; the story concludes with Jesus announcing that they are guilty of an eternal sin and will not be "forgiven."(Lane, 1974: 157; Watts, 1997: 194-210)

Prophetic warnings like the one found in Mark 4 occur throughout the gospel, and they usually appear alongside quotations of Hebrew Scripture. In Mark's prologue, the gospel is presented through the lens of God's salvation as portrayed in Isa 40 as well as God's judgment as described in Mal 3. In the story of Jesus causing a disturbance on the Temple premises, Jesus alludes to

\footnotetext{
23 Other texts that make use of this motif, such as John 12:39-40 and Acts of Thomas 1:82, also have "seeing" before "hearing."

24 Hurtado (1983; Jones, 1995: 299; Dodd, 1961: 4; France, 2002: 201)

25 Snodgrass emphasizes the function of Jesus's parables as "prophetic instruments," the language of the OT prophets in contexts of judgment and indictment (Snodgrass, 2008: 159).

26 See also Bailey (1998: 172).
}

William Loader, Boris Repschinski, Eric Wong (Eds.)

Matthew, Paul, and Others: Asian Perspectives on New Testament Themes

(C) 2019 innsbruck university press, ISBN 978-3-903187-66-5, DOI 10.15203/3187-66-5 
Jeremiah's warnings against the Temple when he calls it a "den of thieves." Likewise, the parable of the vineyard in Mark 12 is a devastating condemnation against the present ruling Jewish authorities, further reinforcing Mark's intention to make one's response to Jesus the determining factor of whether one is included within God's kingdom and plan of salvation. Despite the ability of the parables to further confound those who are rebellious towards God, Mark's Jesus repeatedly invites his listeners to "hear" ("let those who have ears, hear!" Cf. Mark 4:9, 4:15-16, 18, 20, 23-24, 33). The controlling metaphor in the Parable of the Sower has to do with hearing; the action of the various types of soils receiving the sown seed is an image for hearing the word of God. Mark's Jesus is also portrayed as performing miracles that include the healing of the deaf (Cf. Mark 7:32, 37; 9:25). In light of this data, the perplexing quotation of Isa 6, used in connection with the Parable of the Sower, has two major functions that are crucial to Mark's overarching themes and emphases (Beavis, 1989) First, it is a sobering condemnation against those, especially the Jewish religious authorities, who reject Jesus and his proclamation of the kingdom of God (Dodd, 1961: 146) Just like their ancestors who were also rebellious towards God and unable to understand Isaiah's message, now too are they standing against God and unable to understand Jesus's teaching. On the other hand, the promise of healing and forgiveness remains for those who are receptive to Jesus; there was a remnant in Isaiah's day who escaped God's wrath and the same hope remains for those in Jesus's day who "have ears to hear" (Snodgrass, 2008: 160).

\section{Luke's Use of Isaiah}

As suggested earlier, Luke seems to be dependent on Mark's quotation rather than quoting Isa 6:9-10 directly. This can be seen by the language and sequence of actions in Luke 8:10, which resembles that of GMark rather than Isaiah. Like GMark, "seeing" precedes "hearing," and the verbs are altered from $2^{\text {nd }}$ person to the $3^{\text {rd }}$ person. Luke's version is also a truncated version of GMark that omits the second section; there is no mention of turning or being healed or forgiven. However, Craig Blomberg cautions against mistaking "stylistic redaction" for 
"theological redaction." ${ }^{27}$ For example, although it appears that Luke has omitted GMark's "lest they should turn and be forgiven," he may just have moved this idea to the following section, in the interpretation to the Parable of the Sower that follows (Marshall, 1978: 321) In Luke 8:12, the ones "along the path" are those who hear the "word of God" but have it removed from their hearts by the devil- their fate is that they will not "believe and be saved." Luke also abbreviates GMark's "seeing, they might see and not perceive" to "seeing they might not see" and "hearing, they might hear and not understand" to "hearing they might not understand" removing the Semitic idiomatic use of repetition for emphasis (Guelich, 1989: 210) The result is a condensed and simplified version of GMark that does not appear to acknowledge the source of the Isaianic text nor understand its fuller meaning. (Hultgren, 2000: 464) On the surface, the barely discernible Isaianic quotation in Luke simply implies that Jesus speaks in parables in order to confound those on the outside without further explanation. ${ }^{28}$ However, over against Mark and Matthew, Arland Hultgren notes that there are no clear "outsiders" or "those" to whom Jesus

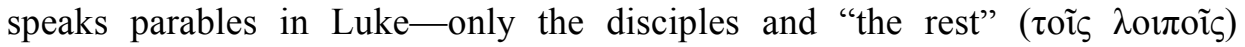
(Hultgren, 2000: 464) But here, too, Blomberg's warning against confusing stylistic changes for theological ones is also pertinent. In the Acts of the Apostles, a work considered by most scholars to be written by the same author as the Gospel of Luke,(Green, 1997: 6-11) the rejection of Paul by the Jews in Rome is also depicted in terms of Isa 6:9-10 (Garland, 2011: 344) In Acts 28:25-27, Luke identifies the Jews who reject Paul with those who reject the prophet Isaiah, and he produces the entire text of Isa 6:9-10 (LXX version) verbatim:

So they disagreed with each other; and as they were leaving, Paul made one further statement: "The Holy Spirit was right in saying to your ancestors through the prophet Isaiah, 'Go to this people and say, You will indeed listen, but never understand, and you will indeed look, but never perceive. For this people's heart has grown dull, and their ears are hard of hearing, and they have shut their eyes; so that they might not look with their eyes, and listen with their

27 Blomberg cautions against mistaking "theological redaction" for "stylistic redaction" (Blomberg, 1990: 122-123).

28 Nolland refers to Luke's citation of Isaiah as "brief to the point of being almost cryptic," and considers it to be more primitive than the Markan or Matthean parallels (Nolland, 1989: 380).

William Loader, Boris Repschinski, Eric Wong (Eds.)

Matthew, Paul, and Others: Asian Perspectives on New Testament Themes

(C) 2019 innsbruck university press, ISBN 978-3-903187-66-5, DOI 10.15203/3187-66-5 
ears, and understand with their heart and turn — and I would heal them.' (Acts 28:25-27)

This suggests that Luke may have been aware of the Isa 6 text but decided to abbreviate Mark's text, for reasons of expediency, or the content he omitted did not fit into his immediate literary concerns (Hultgren, 2000: 464; See also Marshall, 1978: 321) Remarkably, a comparison with other Lukan passages that are dependent on Mark shows a similar pattern. In Mark 1:2, Mark mentions the prophet Isaiah but includes a composite quotation of both Isa 40:3 and Mal 3:1. Luke acknowledges Mark's reference to Isaiah and but omits the quotation of Mal 3:1, although it appears in a later pericope about John the Baptist in Luke 7:27. In the pericope where Jesus forbids divorce except in the case of adultery in Mark, it is accompanied with a reference to Gen 1:27; Matthew (Matt 19:4-5) includes this reference but it is absent in Luke's account (Luke 16:18). Luke also abbreviates Mark's quotation of Ps 118:22-23 (Mark 12:10-11) at the end of the Parable of the Vineyard in Luke 20-by contrast, Matthew follows GMark and has the full text. There are many unique Lukan passages in which the Hebrew Scriptures is quoted, but it appears that either Luke did not always understand or agree with Mark's selection and interpretation of the Hebrew Scriptures, or he simply omitted them out of expediency and stylistic purposes (Blomberg, 1990: 106-107).

\section{Matthew's Use of Isaiah}

Like Luke, Matthew follows Mark's quotation initially, so that "seeing" precedes "hearing," but omits the second half of the quotation that mentions turning and forgiveness. However, unlike Luke, Matthew is cognizant of the fact that the quotation is from Isaiah, because after abbreviating Mark's quotation, he explicitly identifies the source as being from Isaiah, and introduces a lengthy quotation of Isa 6:9-10 that is nearly identical to the version found in the LXX (Matt 13:14-15) (Osborne, 2010: 510) Throughout his gospel, Matthew tends to identify Mark's usage of the Hebrew Scriptures and quoting that text more precisely. For example, when Mark mentions the "desolating sacrilege set up where it ought not to be..." in the Olivet discourse (Mark 13:14), Matthew recognizes this to be a reference to Daniel and mentions him by name (Matt 24:15). In Mark 1:2 when Mark mentions the prophet Isaiah but proceeds to give a composite citation that includes a text from Malachi, 
Matthew likewise recognizes that the quoted text is not from Isaiah and removes the prophet's name. In Mark 13:26, where it says that they will see the Son of Man "coming in clouds," Matthew's version has "coming on the clouds of

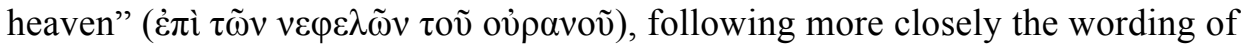
the LXX.

Where he does follow Mark's quotation of Isa 6:9-10, Matthew makes some notable changes to Mark's text. First, although he abbreviates Mark's "seeing, they might see and not perceive" and "hearing, they might hear and not understand" doublet the same way Luke does, the verb ovvíovoiv (they do not understand) is taken out of the clause and made to stand on its own, with the result that in Matthew's version there are three independent verbs instead of two: they do not hear, they do not see, they do not understand. It is not difficult to see why Matthew might have adapted Mark's text this way. The tripartite pattern follows the section in Isa 6:10, where "understanding," "hearing," and "seeing" are listed separately. In other words, Matthew recognizes that Mark is quoting the second section of Isa 6:9-10 and not the first (where ovvíovoiv belongs to the hearing clause) and attempts to insert ovvíovoiv as an independent verb to mirror Isaiah's text more closely. Klyne Snodgrass has

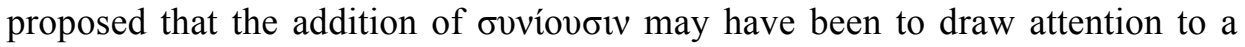
"understanding with the heart," which is more than merely hearing and corresponds to Matthew's interest in the significance of Jesus's teaching. ${ }^{29} \mathrm{He}$ writes: "Whereas Mark asks, 'Do you really hear Jesus' message?' Matthew asks, 'Do you really understand with your heart?"' (Snodgrass, 2008: 152).

Matthew also changes Mark's iv $\alpha$ that introduces the quotation with a ö $\tau$ so that all the subjunctive mood verbs are also changed to the indicative mood. This is a change that alters the function of the Isaianic quotation. In Mark, the iv $\alpha$ conjunction means that Jesus tells parables in order to confound those who reject his message. ${ }^{30}$ In Matthew, the ö $\tau$ c conjunction denotes that Jesus tells parables because the people do not hear or see or understand, emphasizing their existing rebellious nature (Hultgren, 2000: 462) The people's hardness of heart prior to the prophet's preaching is already implied in the Hebrew and Aramaic

(Hultgren, 2000: 463; Snodgrass, 2008: 173).

30 According to Joachim Jeremias, iv $\alpha$ does not denote purpose but is a formula for introducing a quotation. Even if this is the case, Matthew has altered the conjunction to remove any ambiguity (Jeremias, 1963: 17). See also Lane (1974: 159).

William Loader, Boris Repschinski, Eric Wong (Eds.)

Matthew, Paul, and Others: Asian Perspectives on New Testament Themes

(C) 2019 innsbruck university press, ISBN 978-3-903187-66-5, DOI 10.15203/3187-66-5 
versions of Isaiah, but the LXX and the Peshitta make this point explicitly (Watts, 2007: 152) In this regard, Matthew adapts Mark's quotation in light of the LXX's interpretation of Isa 6:9-10, which clarifies the reasons for God's judgment upon Judah (Blomberg, 1990: 115) This is confirmed by the verses that follow, where Matthew unmistakably quotes from a Septuagintal form of Isa $6: 9-10 .^{31}$

\begin{tabular}{|c|c|c|}
\hline \multirow{3}{*}{ 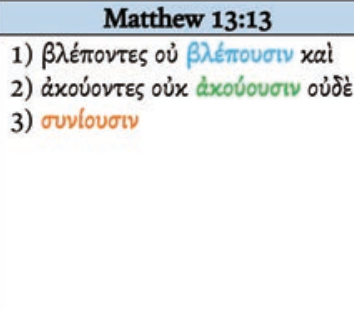 } & Mark 4:12 & Isa 6:9-10 \\
\hline & 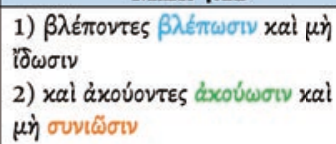 & 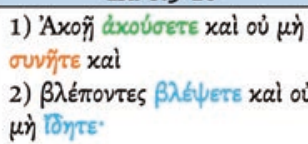 \\
\hline & & 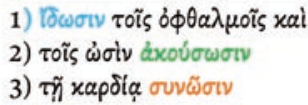 \\
\hline
\end{tabular}

Figure 6: Matthew's Reliance on Mark Versus Isaiah

As in the LXX, Matthew's emphasis is on the deplorable condition of the people to whom the prophetic announcement is directed, rather than the agency of the prophet (Arida, 1994: 219; Hagner, 2000: 375) In Matt 13:14, Matthew's

\begin{tabular}{|c|c|}
\hline Isa 6:9-10 (LXX) & Matt 13:14-15 \\
\hline 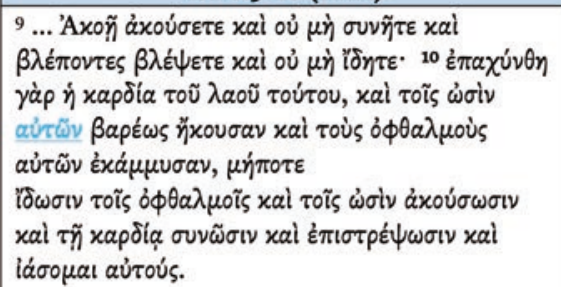 & 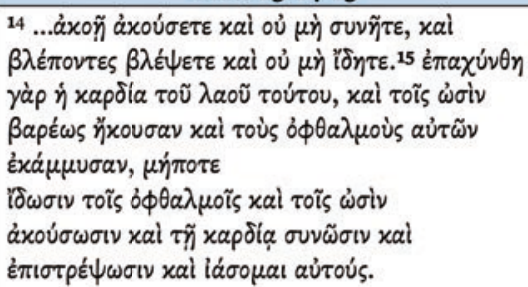 \\
\hline
\end{tabular}

Figure 7: Matthew's Almost Verbatim Quotation of Isa 6:9-10 (LXX)

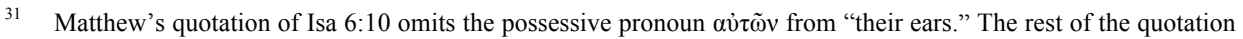
is reproduced verbatim. LXX text taken from Rahlfs (2007).

William Loader, Boris Repschinski, Eric Wong (Eds.)

Matthew, Paul, and Others: Asian Perspectives on New Testament Themes

(C) 2019 innsbruck university press, ISBN 978-3-903187-66-5, DOI 10.15203/3187-66-5 
Jesus says that those who reject his message now are fulfilling the words that Isaiah spoke about the recalcitrant Jews long ago. While this is the only occurrence of the verb $\alpha \dot{v} \alpha \pi \lambda \eta \rho$ ó $\omega$ ("I completely fulfil"), the cognate verb $\pi \lambda \eta \rho$ ó $\omega$ ("I fulfil") is used a total of 16 times in Matthew, often in the context of fulfilment of the Law and the Prophets (o vó $\mu$ o $\varsigma \alpha i$ oi $\pi \rho \circ \varphi \tilde{\eta} \tau \alpha$ ), the scriptures

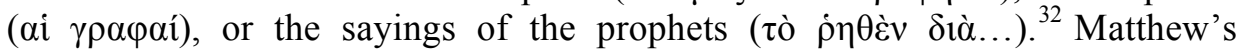
understanding of fulfilment has a typological function that goes beyond a simple prophecy-fulfilment schema, towards seeing how the Scriptures correspond to situations in his own time (Blomberg, 2007: 48) Klyne Snodgrass understands typology as "correspondence in history" and describes it thus: "Climactic events in Israel's history become the paradigms by which new events are explained"(Snodgrass, 1994: 38). In the same way that the people of Judah failed to heed Isaiah's message and fell under God's judgement, those who reject Jesus's message are in danger of meeting the same fate. ${ }^{33}$ Moreover, just as there remained a remnant in Isaiah's day, "a stump" that survives God's judgment; so now can there be a people who remain faithful to God.

\section{Summary}

In summary, at the point where the three Synoptic parallels converge concerning Isa 6:9-10, GMark contains the most detailed quotation, followed by GMatthew and then GLuke. Mark's version contains details from both Isa 6:9 and 6:10, while Matthew's and Luke's quotations are limited to Isa 6:9 only. All three gospels reverses the order of the clauses "seeing" and "hearing" found in Isaiah (France, 2007: 512; Nolland, 2005: 535) All three adaptations of the Isaiah text change the person and mood of the verbs in order to appropriate the prophecy into their respective narratives. Mark and Luke both use the conjunction iv $\alpha$ to introduce the quotation, which emphasizes Jesus's agency in hardening the people's hearts, whereas Matthew uses ö $\tau$, which underscores the fact that the people's hearts are already hardened, and the reason for God's judgment. It is likely that both ideas of God's agency in judgment and the people's culpability are already present in the Hebrew scriptures as

\footnotetext{
32 Law \& Prophets: Matt 5:17; Scriptures: Matt 26:54, 56; Prophetic sayings: Matt 1:22; 2:15, 17, 23; 3:15; 4:14; $8: 17 ; 12: 17 ; 13: 35 ; 21: 4 ; 27: 9$.

33 (France, 1971: 68).
}

William Loader, Boris Repschinski, Eric Wong (Eds.)

Matthew, Paul, and Others: Asian Perspectives on New Testament Themes

(C) 2019 innsbruck university press, ISBN 978-3-903187-66-5, DOI 10.15203/3187-66-5 
demonstrated by the MT, ${ }^{34}$ but the wording in the LXX and Peshitta are altered so as to highlight the people's stubbornness and downplay God's agency (Pao \& Schnabel, 2007: 306).

Mark adapts Isaiah's text freely, omitting certain segments and combining other sections with creativity. Mark omits the beginning part of Isa 6:10a and details about the people's heart becoming dull. Although it looks like Mark has inverted Isaiah's "hearing" and "seeing," it is more likely that he follows the order of Isa 6:10b, which has the sequence: "seeing," "hearing," "understanding," "turning," and "being healed." "Wh While Mark's wording is similar to that of the LXX, his quotation aligns more closely with the MT version that emphasizes God's agency in hardening hearts and the Targum that interprets "healing" to mean "forgiveness." Luke's quotation resembles Mark's text more than it does Isaiah's. Luke follows GMark's order of "seeing" before "hearing" but condenses Mark's/Isaiah's triplet structure into a doublet (Marshall, 1978: 322) Matthew's quotation attempts to edit Mark's jumbled Isaiah quotation by changing the grammar to preserve the "seeing," "hearing," and "understanding" triplet, before giving up and identifying the source and providing his own precise quotation of Isaiah from the LXX (See also France, 2007: 515) It is noteworthy that Matthew also takes the approach of the LXX towards the text by emphasizing the people's obduracy and downplaying God's agency in hardening the people's hearts. ${ }^{36}$

\section{Implications of Citational Patterns for Synoptic Studies}

These parallel passages provide a lens for observing the citational patterns of the Synoptic evangelists as a way to gain insight into their scribal behaviour and how they handle and adapt source materials. Synoptic scholars such as Robert Derrenbacker, Jr., for example, employ the study of scribal practices to evaluate

\footnotetext{
34 Isaiah chs. 1-5 is God's uncompromising condemnation of Judah's unfaithfulness; Ch. 6 is God's judicial response to Judah's idolatry (Arida, 1994: 217).

35 But see also the usual order of "seeing" before "hearing" in texts such as Deut 29:4; Jer 5:21; Ezek 12:2; Mark 12:39; Mark 18:8; Acts of Thomas 1:82.

36 Observe also the pervasive theme of God hardening Pharaoh's heart in the Exodus, esp. Ex 4:21; 7:3, 13-14, 22; $8: 15,19,32 ; 9: 7,12,34-10: 1 ; 10: 20,27 ; 11: 10 ; 14: 4,8,17$ (Drury, 1985: 41-42).
}

William Loader, Boris Repschinski, Eric Wong (Eds.)

Matthew, Paul, and Others: Asian Perspectives on New Testament Themes

(C) 2019 innsbruck university press, ISBN 978-3-903187-66-5, DOI 10.15203/3187-66-5 
and enrich hypotheses of source and redaction. ${ }^{37}$ These studies take into account the conventions and limitations of contemporary scribal activity, and depend on the assumption that the evangelists have a consistent literary style and method of adapting material (Garrow, 2016: 219) The study of citational patterns in the Synoptics with regard to the Hebrew Scriptures can be applied to this area of study by confirming the consistency of Synoptic scribal behaviour of the evangelists and the lending support to theories about scribal limitations and conventions.

The triple tradition text under study provides some useful insights for the study of the Synoptic Problem, because the text of Isa 6:9-10 gives us with one extra data point with which to triangulate our position. For example, these parallel texts provide a clear picture in favour of Markan Priority. If Matthew's gospel was composed first, then he would have included two separate quotations of Isa 6:9-10, one paraphrase that is in parallel with Mark and Luke, which transposes "seeing" with "hearing," and a fuller, more precise quotation. And then Mark would have had to omit Matthew's identification of Isaiah, as well as the fuller and more precise quotation in favour of the shorter paraphrase, which he then attempts to expand, albeit it imprecisely, while ignoring the full text of Isaiah that was already before him! Also, if Matthew was composed first, then Mark and Luke purposely changed Matthew's intention to draw attention to the obduracy of the people with the more obscure interpretation of Jesus speaking in parables in order to confound his listeners. In general, it is far more likely for the shorter and more difficult reading to be the original text, the one on which later versions attempt to expand and clarify.

Likewise, Luke would have had to omit Matthew's fuller quotation of Isaiah and choose the shorter version, the one that is more obscure and the order of which is mixed up (Garrow, 2016: 216) The data shows that, more likely, Matthew was attempting to improve upon Mark's quotation by aligning it closer to the Isaiah text, and then providing the actual text by way of elaboration. By the same logic, it is unlikely that Luke was written before Mark, because throughout this pericope Luke's language and grammatical expression is superior to Mark's. Luke mentions that the disciples are given "to know" the mysteries of the kingdom of God (Luke 8:10), this is a clarification of what

37 (Derrenbacker 2011:, 435-458; Derrenbacker, 2005).

William Loader, Boris Repschinski, Eric Wong (Eds.)

Matthew, Paul, and Others: Asian Perspectives on New Testament Themes

(C) 2019 innsbruck university press, ISBN 978-3-903187-66-5, DOI 10.15203/3187-66-5 
Mark says; it is much more difficult to think of why Mark would have omitted "to know" if Luke was original. A glance at the context of Luke 8:9-10 reveals that Luke's language is terse compared to Mark's; he tends to minimize Mark's words in general, even outside of the Isaiah quotation. It makes better sense that it is Luke who uses GMark as a template after abbreviating GMark and improving upon his grammar and language (E.g. Farmer, 1964: 96) As mentioned earlier, even though GLuke contains many references to the Hebrew Scriptures, Luke tends to downplay Mark's use of the Old Testament, abbreviating some of them and omitting others.

Mark's understanding of the Hebrew Scriptures can be observed through his citational practices in this passage. Mark exhibits a loose and periphrastic style of citation that does not seek to preserve the grammar, structure, nor order of the source text. He also freely adapts the source text to fit his own literary agenda. Be that as it may, Mark's seemingly haphazard mashup of Isaiah reveals a profound understanding of the theological context of Isa 6 that may not have been fully apparent to his Synoptic editors. ${ }^{38}$ While Mark has vocabulary in common with the LXX version of Isa 6 , his quotation aligns more closely with the MT and Targumic versions that emphasize God's agency in hardening the people's hearts. Mark's allusion to the original sense of Isa 6 is significant because it is not merely a description of a dull and obstinate people using Isaianic language - it is an ironic declaration of judgment.

Isaiah's announcement in the MT is a divine pronouncement of judgment against rebellious Judah; Mark clearly understands Jesus's teaching to have a similar function. The Parable of the Sower gives various reasons for why someone might reject the "word" (Mark 4:13-20). Some reject it due to the trouble or persecution accepting it brings. Others are led astray because of "the cares of the world, the lure of wealth, and the desire for other things." Still others do not receive the word at all due to demonic influences. The irony is thick-the scribes from Jerusalem certify Jesus casts out demons by the power of Beelzebul, but Jesus says that their inability to understand him is because of Satan's work in their lives. Jesus' speaking in parables will function as judgment against those who see but do not see, who hear but do not hear. For those who have ears to hear, i.e. his disciples, more understanding will be given,

38 Luke alters the disciples' question to link Isaiah 6 to specifically to the Parable of the Sower, rather than to all of Jesus' parables.

William Loader, Boris Repschinski, Eric Wong (Eds.)

Matthew, Paul, and Others: Asian Perspectives on New Testament Themes

(C) 2019 innsbruck university press, ISBN 978-3-903187-66-5, DOI 10.15203/3187-66-5 
but for those who refuse to listen, i.e. his enemies, even what understanding they have will be taken away (Bailey, 1998: 188; Watts, 2017: 78).

The comparison of the Synoptic use of Isa 6:9-10 appears to support Markan Priority, but what about the relationship between the other two gospels, Matthew and Luke? Under the umbrella of Markan Priority, three dominant theories have been proposed to explain the literary relationships between Matthew and Luke in relation to Mark: 1) The Two Document Hypothesis, 2) The Farrer Hypothesis, and 2) The Matthew Conflator Hypothesis. The Two Document Hypothesis is a variation on B. H. Streeter's Four Source Hypothesis, which proposes that Matthew and Luke are both dependent on Mark and Q but independent of each other. The Farrer Hypothesis and the Matthew Conflator Hypothesis are theories that do not require the postulation of a hypothetical documentary source such as Q. According to the Farrer Hypothesis, Mark was written first, Matthew second, and Luke, writing last, made use of both Mark and Matthew. The Matthew Conflator Hypothesis maintains that Matthew was written last, and conflated Mark and Luke with is other sources to compose his gospel. Each of these theories solve some problems while introducing others, and it is not the aim of this essay to decide which one is correct. I will also not be able to introduce or fully describe each theory. Instead, I will apply the observations of the current study on citational patterns to each of these theories as an experiment to see if anyone one theory makes the best sense of this particular data set of evidence, specifically with regard to Matthew's relationship with Luke. I will begin with the Two Document Hypothesis, followed by the Farrer Hypothesis, and conclude with the Matthew Conflator Hypothesis.

\section{The Two Document Hypothesis}

The present study of citational patterns poses difficulties for the Two Document Hypothesis because of the "minor agreements" that exist between Matthew and Luke over against Mark. ${ }^{39}$ For example, Matthew's knowledge of both Luke

39 E.g. The Healing of the Woman with a Haemorrhage [Matt 9:20 // Mark 5:27 // Luke 8:44], The Healing of the Paralytic [Matt 9:7-8 // Mark 2:12 // Luke 5:25-26], The Trial of Jesus [Matt 26:67-68 // Mark 14:65 // Luke 22:63-65] (Farmer, 1964: 94-177; Garrow, 2016: 222; Hultgren, 2000: 463; Marcus, 1986: 76; Snodgrass, 2008:

William Loader, Boris Repschinski, Eric Wong (Eds.)

Matthew, Paul, and Others: Asian Perspectives on New Testament Themes

(C) 2019 innsbruck university press, ISBN 978-3-903187-66-5, DOI 10.15203/3187-66-5 
and Mark would account for why neither Matthew and Luke distinguish the Twelve from the rest of the disciples, why both omit Jesus and his disciples were alone, why both pluralize the word "mystery" and include the infinitive "to know," and why both omit the final colon of Isa 6:10 that mentions repentance and healing. In the interpretation of the parable, both Matthew and Luke contain the detail about the seed sown in the listener's "heart."(Wenham, 1974: 310) (Matt 13:9 / Luke 8:12) During the actual quotation of Isa 6:9, Matthew and Luke resemble each other more than they do Mark.

\begin{tabular}{|c|c|c|c|}
\hline Mark 13:10 & Matt 13:13 & Luke 8:10 & Isa 6:9 \\
\hline 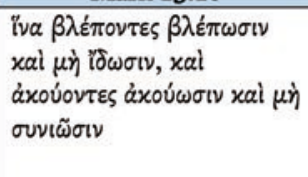 & 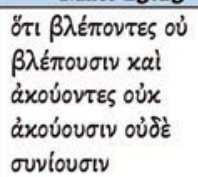 & 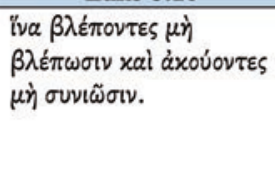 & 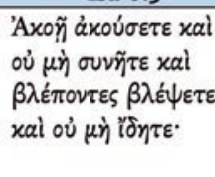 \\
\hline
\end{tabular}

Figure 8: Matthew and Luke over against Mark with reference to Isaiah

John Nolland, following Matthean scholar Ulrich Luz, has proposed that Luke and Matthew were relying on a separate common source, a pre-Marcan text that contains these details, ${ }^{40}$ and others have suggested that these minor agreements could be the result of coincidental editing, ${ }^{41}$ but the cumulative evidence suggests that more likely other factors are at play. What if, as the Farrer and Matthew Conflator hypotheses suggest, Matthew or Luke did make use of the other?

150; Wenham, 1972: 27) These minor agreements can also be found in the Interpretation of the Parable of the Sower (Wenham, 1974: 310).

40 Nolland admits that "[t]here are definite indications that Luke has utilized here another source along with Mark 4:10-12. These indications concentrate especially in v 10a where Matthew and Luke agree against Mark with o

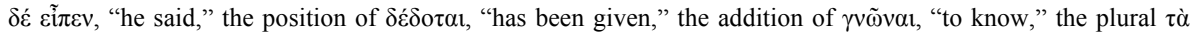

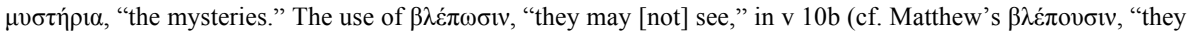
do [not] see") probably indicates that the second source also alluded to Isa 6:9 (most likely in a brief form like the present $v$ 10b [cf Matt 13:13]). It is not possible to delineate further the scope of the second source or any context for it..." However, what if they are not dependent upon another source, but each other? (Nolland, 1998: 377-379, xxxi). See also Marcus (1986: 84-85; Snodgrass, 2008: 151; Wenham, 1974: 305)

$41 \quad$ As Streeter proposed (Streeter, 1924: 295-331).

William Loader, Boris Repschinski, Eric Wong (Eds.)

Matthew, Paul, and Others: Asian Perspectives on New Testament Themes

(C) 2019 innsbruck university press, ISBN 978-3-903187-66-5, DOI 10.15203/3187-66-5 


\section{The Farrer Hypothesis}

The Farrer Hypothesis, introduced by Austin Farrer in 1955 (also now known as the Farrer-Gould-Goodacre Hypothesis), ${ }^{42}$ proposes that Matthew was dependent on Mark, and Luke was dependent on both Matthew and Mark (See also McNicol, Dungan, \& Peabody, 1996) David Wenham's study of the Interpretation of the Parable of the Sower contends that the similarities between Luke and Matthew in that passage is "eminently compatible with the view that Luke knew and was influenced by the Matthean tradition, even when he diverges from it."(Wenham, 1974: 312) Luke is an editor of Mark's work-he removes unnecessary content (e.g. the condensing of "seeing, they might see but not perceive" to "seeing the might not see") but will also add details to improve Mark's clarity, either grammatically or semantically, when needed (e.g. the pluralization of "mystery," the addition of "to know"). If Luke was composed last and dependent on Matthew, it may be difficult to explain why Luke would knowingly disregard Matthew's acknowledgement of Mark's dependence on Isaiah and Matthew's attempt to supplement Mark's text with a more precise quotation. However, Luke also has a habit of truncating or removing Mark's quotations of the Hebrew Scriptures that he does not believe to be essential or relevant to the context, and the quotation of Isaiah is a good example of this. ${ }^{44}$ The fact that Luke uses Isa 6:9-10 again in its fuller LXX form in Acts 28:26-27 suggests that perhaps Luke was aware of the LXX's understanding of the passage but decided to go with Mark's version instead. The result of Luke's editing is a more compact version of Mark's text that has greater clarity and reflects Luke's own literary concerns. Against Mark's contention that Jesus's opponents will never be forgiven, Luke's gospel contains a programmatic plan of salvation, (Blomberg, 1990: 107; McNicol et al., 1996: 39) of which "forgiveness" is an important cornerstone.

However, there are factors that also undermine the theory of Lukan dependence on Matthew, rather than the other way around. First, In regard to

\footnotetext{
42 (Farrer, 1955: 55-88). In Farmer's analysis, Luke is also dependent on Matthew, although he advocates the Griesbach hypothesis ( 2 Gospel hypothesis) and contends that Matthew was written first and Mark last (Farmer, 1964: 200-201).

43 Horman (1979: 343).

44 Luke's "characteristic" omission of the OT proof text is also noted in McNicol et al. $(1996: 34,124)$
}

William Loader, Boris Repschinski, Eric Wong (Eds.)

Matthew, Paul, and Others: Asian Perspectives on New Testament Themes

(C) 2019 innsbruck university press, ISBN 978-3-903187-66-5, DOI 10.15203/3187-66-5 
the so-called "minor agreements" mentioned above-if they are to be taken to be evidence of conflation, that is, a third author combining elements of the previous two, then this would not be characteristic observed elsewhere in Luke's writing. According to the Farrer hypothesis, Luke tends to separate, or "unpick" his sources rather than conflating them together. Second, Matthew's text also includes a bit of double tradition material often ascribed to "Q." After the lengthy Isaianic quotation, Matthew contrasts the recalcitrant people who do not listen with the disciples, whose eyes do see and whose ears do hear. (Matt 13:16-17) The disciples are blessed because "prophets and righteous people" have longed to see and hear what they can now see and hear, presumably the good news of the Kingdom of Heaven, as inaugurated by the figure of Jesus (See Lane, 1974: 158) This same passage can be found in Luke 10:23-24, with the exception that instead of "righteous people," Luke has "kings" ( $\beta \alpha \sigma i \lambda \varepsilon \tilde{i} \varsigma)$ who longed to see what the disciples see. Instead of inserting this pericope within the crux interpretum of the Parable of the Sower, Luke places it after a passage in which Jesus thanks God for revealing himself through the Son. (Luke 10:21-22) According to the Farrer hypothesis, Luke would have intentionally displaced this paragraph into a different context, despite the correspondence of "seeing" and "hearing" with the Isaianic quotation in the Matthean arrangement. Furthermore, the strong emphasis on the privileged status of the disciples is a recurring theme in this passage - it is difficult to understand why Luke would have omitted this relevant passage. These observations suggest that perhaps another theory might provide a better explanation of the literary phenomena (Garrow, 2016: 222).

\section{The Matthew Conflator Hypothesis}

The curious similarities between Matthew and Luke over against Mark that may also lend support to the "Matthew Conflator Hypothesis" (MCH), ${ }^{45}$ a theory that reconsiders the possibility that Matthew might have been written last, and was dependent on Luke as well as Mark (Garrow, 2016: 222) According to the $\mathrm{MCH}$, Matthew is written last among the Synoptics and is often motivated to

45 This view of Markan Priority/Matthean Posteriority was first proposed by Christian Gottlob Wilke in 1838:

"Wilke thought that Matthew and Luke copied Mark, but that Matthew also copied Luke..." (Farmer 1964, 34 n. 54).

William Loader, Boris Repschinski, Eric Wong (Eds.)

Matthew, Paul, and Others: Asian Perspectives on New Testament Themes

(C) 2019 innsbruck university press, ISBN 978-3-903187-66-5, DOI 10.15203/3187-66-5 
conflate related material from different sources, and even when he follows Mark he supplements it with material from Luke if he is able. Alan Garrow summarizes the implications of the $\mathrm{MCH}$ as such: "there are substantial obstacles to Luke's use of Matthew; Matthew's use of Luke is indeed an 'obvious' explanation for the Double Tradition; and the phenomenon of Alternative Primitivity does suggest the presence of an additional source or sources, 'Q,' used by both Luke and Matthew." $\mathrm{MCH}$ makes better sense of the observations in these passages than the 2 Document or Farer hypotheses under the traditional Markan Priority umbrella of compositional theories. One of the main reasons, in my view, is that Matthew's version of the parallel passage is the lengthiest and the most complete. It makes more sense to me to see Matthew as the "last word" on the passage: rearranging Mark, supplying missing bibliographic information, providing a fuller quotation, etc., than for Luke to be a condenser of Matthew that omits important details.

Matthew's scribal activity with regard to the pericopae surrounding the Parable of the Sower can be best described as a creative and interpretive conflation of materials to which he must have had ready access, perhaps by way of codices, giving traction to theories like the $\mathrm{MCH}$. Compared to Luke, Matthew is more prone to deviate from Mark's original meaning. Matthew does not follow Mark's sequence too closely, instead he tries to make sense of Mark's text by re-arranging it. He takes Mark $4: 24-25,{ }^{47}$ the passage about "to those who have more will be given," which appears after Jesus's explanation of the Parable Sower in Mark and he places it within Jesus's explanation for speaking in parables in his gospel (Matt 13:12) (Nolland, 2005: 534) In contrast, Luke follows Mark's sequence much more closely and that passage is found in the same location as it is in Mark. Matthew's access to some version of the LXX is also evident. He corrects Mark in favour of the LXX's sense of Isa 6:910 and is able to reproduce a lengthy and precise quotation of Isa 6:9-10 that contains 47 Greek words. This type of scribal activity, going back and forth between Mark, Luke, the LXX, and perhaps other sources, is best undertaken

46 (Garrow, 2016: 226). Cf. Matt 11:10/Luke 7:27.

47 "Pay attention to what you hear; the measure you give will be the measure you get, and still more will be given you. For to those who have, more will be given; and from those who have nothing, even what they have will be taken away."

William Loader, Boris Repschinski, Eric Wong (Eds.)

Matthew, Paul, and Others: Asian Perspectives on New Testament Themes

(C) 2019 innsbruck university press, ISBN 978-3-903187-66-5, DOI 10.15203/3187-66-5 
with the use of codices rather than scrolls, which were more cumbersome and demanded the scribe to work with one source at a time. These findings support the theory that Matthew was written later rather than earlier, at a time when codices were in use.

\section{Conclusion}

After comparing the three Synoptic adaptations of Isa 6:9-10, I conclude that the data supports Markan Priority but undermines the Two Document Hypothesis insofar as Matthew and Luke were independently composed. As far as whether Matthew or Luke had the "final say" on this passage, the evidence can be used to support both the Farrer Hypothesis or the Matthew Conflator Hypothesis. The direction of influence can go either way. Either Luke was a redactor who condensed Mark's text while inserting Matthean influences, or Matthew was a conflator who enriched Mark's text with help from Luke. Given Matthew's stylized structure and arrangement of the "Double Tradition" traditionally regarded as Q outside this passage, I would lean towards Matthew as the final author because it makes more sense for Matthew to amplify the existing tradition with an identification of the Isaiah context, rather than for Luke to intentionally remove Matthew's contributions while retaining Mark's jumbled quotation. Furthermore, in light of Luke's tendency elsewhere to separate, rather than conflate, his sources, it is more likely for Matthew to be the conflator. Finally, the "Q" material in Matthew's text is also more fitting to the context than its location in Luke, perhaps pointing to the fact that Matthew was the final redactor and not Luke. However, within the limited scope of this particular passage, both options are possible. 


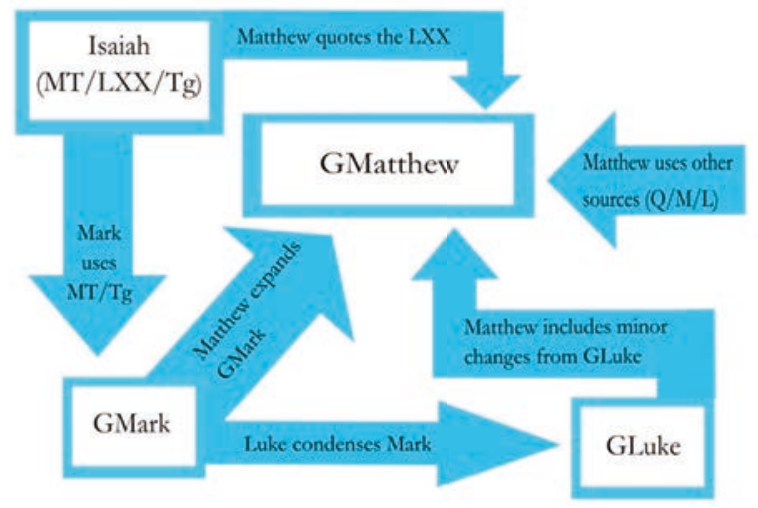

Figure 9: A Proposal with Matthew as the Final Redactor

\section{Bibliography}

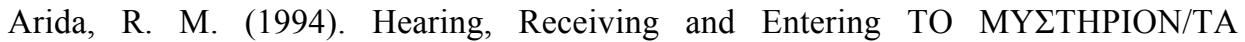

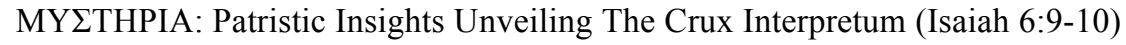
of the Sower Parable. St Vladimir's Theological Quarterly, 38 (1), 211-234.

Bailey, M. L. (1998). The Parable of the Sower and the Soils. Bibliotheca Sacra, 155(June), 172-188.

Beavis, M. A. (1989). Mark's Audience: The Literary and Social Setting of Mark 4.1112 (JSNTSup 33). Sheffield: JSNT Press.

Blomberg, C. L. (1990). Interpreting the Parables. Downers Grove, IL: InterVarsity Press.

Blomberg, C. L. (2007). Matthew. In G. K. Beale \& D. A. Carson (Eds.), Commentary on the New Testament Use of the Old Testament. Grand Rapids, MI: Baker Academic.

Derrenbacker Jr., R. A. (2005). Ancient Compositional Practices and the Synoptic Problem. Leuven: Peeters.

Derrenbacker Jr., R. A. (2011). The "External and Psychological Conditions under Which the Synoptic Gospels were Written": Ancient Compositional Practices and the Synoptic Problem. In P. Foster, A. Gregory, J. S. Kloppenborg, \& J. Verheyden (Eds.), New Studies in the Synoptic Problem: Oxford Conference, April 2008. Essays in Honour of Christopher M. Tuckett (pp. 435-458). Leuven: Peeters.

Dodd, C. H. (1961). The Parables of the Kingdom. New York, NY: Scribners. 
Drury, J. (1985). The Parables in the Gospels: History and Allegory. New York, NY: Crossroad.

Dungan, D. L. (1999). A History of the Synoptic Problem: The Canon, the Text, the Composition, and the Interpretation of the Gospels. New York, NY: DoubleDay.

Evans, C. A. (1989). To See and Not Perceive: Isaiah 6:9-10 in Early Jewish and Christian Interpretation. Sheffield: JSOT.

Farmer, W. R. (1964). The Synoptic Problem: A Critical Analysis. New York, NY: Macmillan.

Fitzmyer, J. A. (1985). The Gospel according to Luke (Anchor Bib). Garden City, NY: DoubleDay.

France, R. T. (1971). Jesus and the Old Testament: His Application of Old Testament Passages to Himself and His Mission. London: Tyndale.

France, R. T. (2002). The Gospel of Mark: A Commentary on the Greek Text (NIGTC). Grand Rapids, MI: Eerdmans.

France, R. T. (2007). The Gospel of Matthew. Grand Rapids, MI: Eerdmans.

Garland, D. E. (2011). Luke (ZEC). Grand Rapids, MI: Zondervan.

Garrow, A. (2016). Streeter's "other" Synoptic solution: The Matthew conflator hypothesis. New Testament Studies, 62(2), 207-226.

Green, J. B. (1997). The Gospel of Luke (NICNT). Grand Rapids, MI: Eerdmans.

Guelich, R. A. (1989). Mark 1-8:26 (WBC). Nashville, TN: Thomas Nelson.

Hagner, D. A. (2000). Matthew 1-13 (WBC). Nashville, TN: Thomas Nelson.

Horman, J. F. (1979). The source of the version of the parable of the sower in the Gospel of Thomas. Novum Testamentum, 21(4), 326-343.

Hultgren, A. J. (2000). The Parables of Jesus: A Commentary. Grand Rapids, MI: Eerdmans.

Hurtado, L. W. (1983). Mark (Good News). New York, NY: Harper \& Row.

Jeremias, J. (1963). The Parables of Jesus, trans. S. H. Hook. New York, NY: Scribners.

Jones, I. H. (1995). The Matthean Parables: A Literary and Historical Commentary (Studien zu). Leiden: Brill.

Lane, W. L. (1974). The Gospel According to Mark. Grand Rapids, MI: Eerdmans.

Linnemann, E. (1992). Is There a Synoptic Problem? Rethinking the Literary Dependence of the First Three Gospels, trans. Robert W. Yarbrough. Grand Rapids, MI: BakerBooks.

Marcus, J. (1986). The Mystery of the Kingdom of God (SBL Disser). Atlanta, GA: Scholars Press.

Marcus, J. (1999). Mark 1-8 (Anchor Bib). New York, NY: DoubleDay.

Marshall, I. H. (1978). The Gospel of Luke: A Commentary on the Greek Text (NIGTC). Carlisle: Paternoster.

William Loader, Boris Repschinski, Eric Wong (Eds.)

Matthew, Paul, and Others: Asian Perspectives on New Testament Themes

(C) 2019 innsbruck university press, ISBN 978-3-903187-66-5, DOI 10.15203/3187-66-5 
McNicol, A. J., Dungan, D. L., \& Peabody, D. B. (Eds.). (1996). Beyond the Q Impasse: Luke's Use of Matthew: A Demonstration by the Research Team of the International Institute for Gospel Studies. Valley Forge, PA: International Institute for Gospel Studies.

Nolland, J. (1989). Luke 1-9:20 (WBC). Nashville, TN: Word.

Nolland, J. (2005). The Gospel of Matthew: A Commentary on the Greek Text (NIGTC). Grand Rapids, MI: Eerdmans.

Osborne, G. R. (2010). Matthew (ZEC). Grand Rapids, MI: Zondervan.

Oswalt, J. N. (1986). The Book of Isaiah, Chapters 1-39 (NICOT). Grand Rapids, MI: Eerdmans.

Pao, D. W., \& Schnabel, E. J. (2007). Luke. In G. K. Beale \& D. A. Carson (Eds.), Commentary on the New Testament Use of the Old Testament. Grand Rapids, MI: Baker Academic.

Snodgrass, K. (1994). The Use of the Old Testament in the New. In G. K. Beale (Ed.), The Right Doctrine from the Wrong Texts: Essays on the Use of the Old Testament in the New (pp. 29-51). Grand Rapids, MI: BakerBooks.

Snodgrass, K. (2008). Stories with Intent: A Comprehensive Guide to the Parables of Jesus. Grand Rapids, MI: Eerdmans.

Streeter, B. H. (1924). The Four Gospels: A Study of Origins. Treating of the Manuscript Tradition, Sources, Authorship, and Dates. London: Macmillan.

Swartley, W. M. (1994). Israel's Scripture Traditions and the Synoptic Gospels: Story Shaping Story. Peabody, MA: Hendrickson.

Wallace, D. B. (1996). Greek Grammar Beyond the Basics: An Exegetical Syntax of the New Testament. Grand Rapids, MI: Zondervan.

Watts, J. D. W. (2005). Isaiah 1-33 (WBC). Nashville, TN: Thomas Nelson.

Watts, R. E. (1997). Isaiah's New Exodus in Mark (WUNT 88). Tübingen: Mohr Siebeck.

Watts, R. E. (2007). Mark. In G. K. Beale \& D. A. Carson (Eds.), Commentary on the New Testament Use of the Old Testament (pp. 111-250). Grand Rapids, MI: Baker Academic.

Watts, R. E. (2017). The Gospel of Mark: A Commentary on His Use of the Old Testament. Vancouver, BC: Regent College Publishing.

Wenham, D. (1972). The Synoptic Problem Revisited: Some New Suggestions about the Composition of Mark 4:1-34. Tyndale Bulletin, 23, 3-38.

Wenham, D. (1974). The interpretation of the parable of the sower. New Testament Studies, 21(1), 59-80.

William Loader, Boris Repschinski, Eric Wong (Eds.)

Matthew, Paul, and Others: Asian Perspectives on New Testament Themes

(C) 2019 innsbruck university press, ISBN 978-3-903187-66-5, DOI 10.15203/3187-66-5 